p-ISSN 2615-286X | e-ISSN 2798-5075

DOI 1052646

\title{
LITERATURE REVIEW PENGARUH TEKNIK RELAKSASI GENGGAM JARI TERHADAP PENURUNAN NYERI PADA PASIEN POST OPERASI APPENDIKTOMI
}

\author{
Salis Nur Hanafi ${ }^{1}$ Eko Julianto ${ }^{2}$ Sudiarto $^{3}$ \\ ${ }^{123}$ Politeknik Yakpermas Banyumas, Diploma III Keperawatan \\ email:salisnur@gmail.com
}

\begin{abstract}
ABSTRAK
Latar belakang: Apendiksitis dapat didefinisikan sebagai radang usus buntu dan merupakan penyebab paling umum dari abdomen akut apendiksitis membentuk peradangan pada apendiks atau usus buntu yang berakibat penyempitan atau penyumbatan. Di Indonesia peristiwa apendikitis berjumlah sekitar $7 \%$ dari jumlah penduduk yaitu kurang lebih 179.000 orang. Tindakan pada pasien apendiksitis salah satunya adalah dengan cara pembedahan atau yang disebut appendiktomi. Penatalaksanaan appendiktomi ini dapat dilakukan dengan farmakologis maupun non farmakologis. Salah satu terapi non farmakologisnya yaitu dengan cara relaksasi genggam jari. Tujuan : Untuk mengetahui pengaruh teknik relaksasi genggam jari terhadap penurunan nyeri pada pasien post operasi appendiktomi. Hasil : Pada jurnal I setelah diberikan intervensi genggam jari terdapat penurunan tingkat nyeri dari nyeri sedang menjadi tidak nyeri sebanyak 8 orang. Dan pada jurnal II setelah diberikan intervensi genggam jari terdapat penurunan tingkat nyeri dari skala nyeri sedang menjadi skala nyeri ringan. Hal ini dikarenakan pada setiap jari-jari yang terhubung dengan berbagai organ terdapat saluran atau meridian energi. Kondisi relaksasi alamiah akan memicu pengeluaran hormon endorfin atau hormon analgesik alami yang berada di tubuh sehingga menjadikan nyeri berkurang. Kesimpulan: Adanya pengaruh teknik relaksasi genggam jari terhadap penurunan tingkat nyeri pada pasien post apendiktomi.
\end{abstract}

Kata Kunci: Apendiksitis, Tingkat Nyeri, Relaksasi Genggam Jari

Studi literatur : 26 (2010-2020)

ABSTRACT

Background : Appendicitis can be explained as inflammation caused by an infected appendix. These infections can cause acute inflammation and require immediate surgery to prevent complications. The surgical procedure is called an appendectomy, to reduce the risk of perforation, surgery is performed as soon as possible. The effect felt by the patient from the surgery is pain, pain management in a non-pharmacological way, one of which can be done by using finger grip relaxation techniques. Purpose : To determine the effect of finger grip relaxation techniques on reducing pain in postoperative appendectomy patients. Results : In journal I there was a decrease in pain levels after the intervention from moderate pain to no pain as many as 8 people. And in journal II there is a decrease in pain level from moderate pain scale to mild pain scale. This is because in every finger connected to various organs there are channels or energy meridians. Natural relaxation conditions will trigger the release of endorphins or natural analgesic hormones in the body so that pain is reduced. Conclusion: There is an effect of finger grip relaxation techniques on reducing pain levels in post appendectomy patients.

Keywords: appendicitis, pain levels, finger-holding relaxation

Literature study : 26 (2010-2020)

\section{PENDAHULUAN}

Apendiksitis dapat didefinisikan sebagai radang usus buntu dan merupakan penyebab paling umum dari abdomen akut (Sulung \& Rani, 2017). Apendisitis juga dapat dijelaskan sebagai peradangan yang disebabkan karena usus buntu yang terinfeksi. Infeksi ini dapat menyebabkan peradangan akut sehingga memerlukan pembedahan sesegera untuk mencegah komplikasi yang biasanya berbahaya (Hasaini, 2020).

Menurut World Health Organisation (WHO), kejadian appendisitis di dunia sangat tinggi, angka moral apprndisitis 21.000, laki-laki lebih banyak dari pada perempuan, ada sekitar 12.000 
penduduk laki-laki 10.000 penduduk wanita. Di amerika serikat, 70.000 kasus usus buntu terdeteksi stiap tahun (Rahmatun \& Heru, 2020).

Di indonesia peristiwa apendikitis berjumlah sekitar $7 \%$ dari jumlah penduduk yaitu kurang lebih 179.000 orang (Waisani \& Khoiriyah, 2020).

Appendiksitis hanya dapat disembuhkan dengan mengobati usus buntu melalui pembedahan appendiks yang terinfeksi. Appendiktomi dilaksanakan segera mungkin untuk mengurangi resiko perforasi lebih lanjut, seperti peritonitis atau abses (Waisani \& Khoiriyah, 2020).

Apendiktomi yaitu cara pembedahan untuk mengangat apendiks ketika sudah terdiagnosa. Untuk menurunkan resiko perforasi pembedahan dilakukan segera mungkin (Sulung \& Rani, 2017).

Ada 2 jenis penatalaksanaan apendiktomi yaitu dengan pengobatan farmakologi (obat-obatan) dan terapi non farmakologi (tanpa obat). Salah satu terapi non farmakologi yang dapat dilaksanakan yaitu teknik relaksasi genggam jari.

Teknik relaksasi genggam jari merupakan tindakan sederhana untuk mengontrol dan mengembangkan tingkat emosional pada diri. Pada setiap jari-jari yang terhubung dengan berbagai organ terdapat saluran atau meridian energi. Kondisi relaksasi alamiah akan memicu pengeluaran hormon endorfin atau hormon analgesik alami yang berada di tubuh sehingga menjadikan nyeri berkurang (R. A. Wati et al., 2020).

tekanan darahnya terdata berjumlah 9.099.765 (34,60\%). Dari hasil pemeriksaan tekanan darah sejumlah 8.070 .378 orang $(30,4 \%)$ dinyatakan terkena hipertensi. Menurut Jenis kelamin, pada kelompok wanita lebih tinggi presentasenya yaitu sebesar $40,17 \%$ dibandingkan dengan kelompok lakilaki yaitu sebanyak 33,83\%.

Hipertensi adalah penyakit menahun yang membutuhkan pengobatan dan penanganan yang baik.Penderita hipertensi banyak yang tekanan darahnya tidak terkontrol sehingga presentasenya terus meningkat.Sebab itu, penanganan yang baik sangat diperlukan untuk mengendalikan penyakit hipertensi (Tarwoto et al., 2018).

Menurut penelitian (Hayat et al., 2020) tentang "Efektifitas Relaksasi Genggam Jari Terhadap Penurunan Nyeri Pasien Post Op Appendiktomi di Ruang Irna III RSUD P3 Gerung Tahun 2019", pada kelompok perlakuan didapatkan nilai $p$-value sebesar $0,000<\alpha 0,05$ dengan kesimpulan nyeri yang dirasakan sebagian besar responden sebelum diberikan teknik relaksasi genggam jari sebanyak 17 orang $(89,5 \%)$ dan setelah dilakukannya relaksasi genggam jari tidak nyeri sebanyak 8 orang $(42,1 \%)$.

Dari hasil penelitian tersebut, penulis tertarik untuk membuat karya tulis ilmiah berjudul "Literature Review Pengaruh Teknik Relaksasi Genggam Jari Terhadap Penurunan Nyeri Pada Pasien Post Operasi Apendiktomi".

\section{METODE PENELITIAN}

Jenis penelitian yang digunakan adalah penelitian kepustakaan, waktu penelitian 10 November 2020 - 25 Mei 2021, sumber data penelitian yaitu data sekunder berupa literaturliteratur relevan seperti jurnal dan buku, metode pengumpulan data yaitu dokumentasi dan study 
literature, metode analisis data menggunakan metode analisis deskriptif, prosedur penelitian organize, synthesize, identity.

\section{HASIL DAN PEMBAHASAN}

\section{Tabel 1 \\ Persamaan Dan Perbedaan Dari Kedua Jurnal}

\begin{tabular}{|c|c|c|}
\hline Jurnal & Persamaan & Perbedaan \\
\hline Pengaruh & 1.Bertujuan & 1. Jumlah \\
\hline Tehnik & untuk & Responden \\
\hline Relaksasi & mengetahui & Pada \\
\hline Genggam & ada & jurnal 1 \\
\hline Jari & tidaknya & responden \\
\hline Terhadap & pengaruh & berjumlah \\
\hline Penurunan & teknik & 19 orang \\
\hline Skala Nyeri & relaksasi & dan \\
\hline Pada Pada & genggam & dilakukan \\
\hline Pasien Post & jari & selama 1 \\
\hline Appendikto & terhadap & bulan. \\
\hline $\mathrm{mi} \quad \mathrm{di}$ & penurunan & Pada \\
\hline Ruang Irna & tingkat & jurnal II \\
\hline III RSUD & nyeri & Pada \\
\hline P3 Gerung & pasien post & jurnal 2 \\
\hline Lombok & operasi & responden \\
\hline Barat & appendikto & berjumlah \\
\hline (Abdul & mi. & 10 orang \\
\hline Hayat, & 2. Teknik & dan \\
\hline Ernawati, & yang & dilakukan \\
\hline Maelina & diberikan & selama 3 \\
\hline Ariyanti) & saat & bulan.. \\
\hline & intervensi & 2. Karakterist \\
\hline Teknik & kepada & ik \\
\hline relaksasi & responden & responden \\
\hline genggam & yaitu teknik & Pada \\
\hline & genggam & jurnal 1 \\
\hline terhadap & jari. & diketahui \\
\hline intensitas & 3.Dalam & karakterist \\
\hline nyeri pada & kedua & ik \\
\hline pasien post & jurnal & responden \\
\hline apendiktom & diketahui & yaitu \\
\hline & kriteria & dominan \\
\hline (Neila & inklusi dan & berjenis \\
\hline Sulung \& & eksklusi & kelamin \\
\hline Sarah Dian & 4. Sasaran & laki-laki \\
\hline Rani) & yang & Pada \\
\hline & dijadikan & jurnal 2 \\
\hline & sebagai & tidak \\
\hline & responden & diketahui \\
\hline & yaitu & karakterist \\
\hline
\end{tabular}

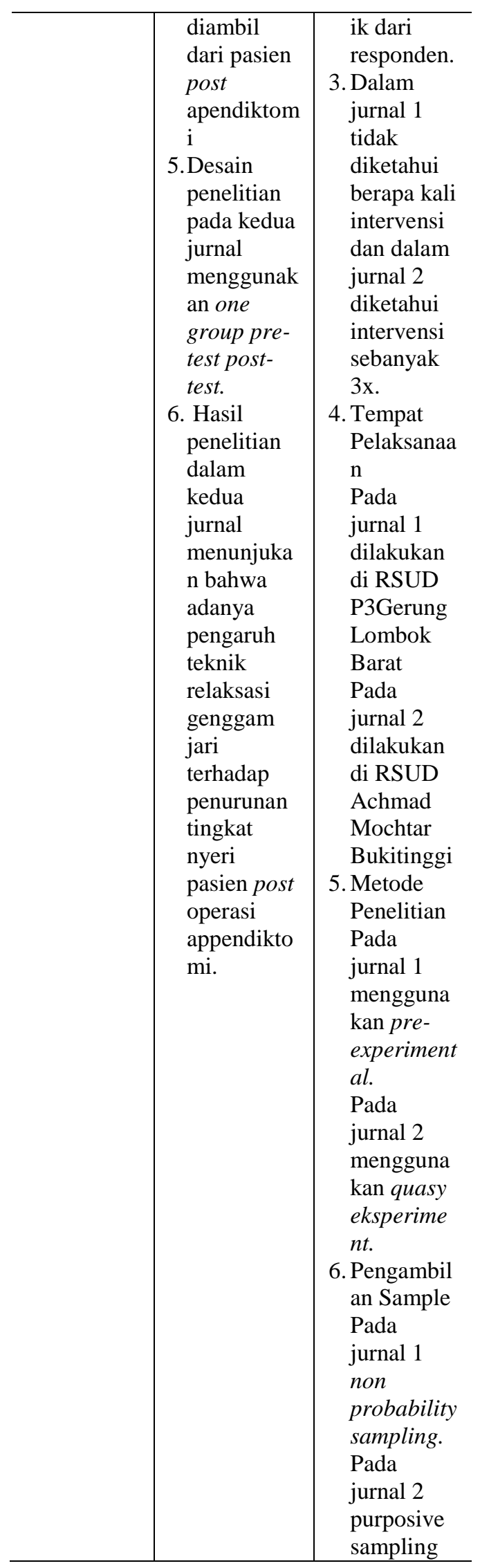


Setelah review dua jurnal didapatkan hasil pada jurnal pertama dengan jumlah responden 19 orang yaitu menyatakan bahwa mayoritas responden berusia 20-25 tahun (7 responden). Sedangkan berdasarkan jenis kelamin yaitu mayoritas berjenis kelamin laki-laki sebanyak 12 responden, dan untuk tingkat pendidikan mayoritas responden berada pada tingkat pendidikan menengah (SMP-SMA) sebanyak 15 orang. Penyakit apendisitis ini dapat mengenai semua umur baik laki-laki maupun perempuan, tetapi lebih sering menyerang laki-laki berusia 10-30 tahun (Rasyid et al., 2019).

Diketahui hasil penelitian pada jurnal pertama terdapat responden sebanyak 19 orang. Frekuensi responden berdasarkan tingkat nyeri sebelum diberikan teknik relaksasi genggam jari didapatkan hasil bahwa mayoritas mengalami nyeri sedang sebanyak 17 orang dan sebanyak 2 orang mengalami nyeri ringan. Dan hasil sesudah diberikan teknik relaksasi genggam jari yaitu mayoritas responden tidak mengalami nyeri sebanyak 8 orang, nyeri ringan sebanyak 7 orang dan nyeri sedang sebanyak 4 orang. Sehingga pada jurnal ini terbukti bahwa teknik relaksasi genggam jari berpengaruh terhadap penurunan tingkat nyeri pada pasien post apendiktomi.

Penurunan tingkat nyeri tersebut dikarenakan bahwa teknik relaksasi genggam jari merupakan salah satu teknik relaksasi yang menggunakan jari tangan yang membuat responden mengalami penuruan nyeri sesudah dilakukanya, karena teknik ini memberikan suatu tindakan untuk membebaskan mental dan fisik dari ketegangan stress sehingga dapat meningkatkan toleransi terhadap nyeri (Hasaini, 2020).

Teknik relaksasi genggam jari yaitu melibatkan genggaman jari dan pengaturan nafas atau nafas dalam. Pada setiap anggota tubuh terdapat aliran energi, dan pada genggaman jari ini aliran energi dipersepsikan sebagai stimulus untuk rileks. Stimulus ini mengaktifkan transmisi serabut saraf A-beta yang lebih besar dan cepat, menurunkan transmisi nyeri melalui serabut $\mathrm{C}$ dan delta-A yang berdiameter lebih kecil, proses ini menghambat stimulus nyeri. Jika tidak ada informasi nyeri yang disampaikan ke otak, maka tidak ada nyeri yang dirasakan. Dengan pengaturan nafas melalui genggaman jari, ketegangan serta kecemasan pasien dapat dikontrol, pasien akan merasa lebih santai dan rileks yang selanjutnya akan menimbulkan tingkat kenyamanan yang lebih baik sehingga intensitas nyeri dapat menurun. Perlakuan relaksasi genggam jari akan menghasilkan impuls yang dikirim melalui serabut saraf aferen non nosiseptor. Serabut saraf non nosiseptor mengakibatkan "pintu gerbang" tertutup sehingga stimulus nyeri terhambat dan berkurang (Pinandita., et al. 2012).

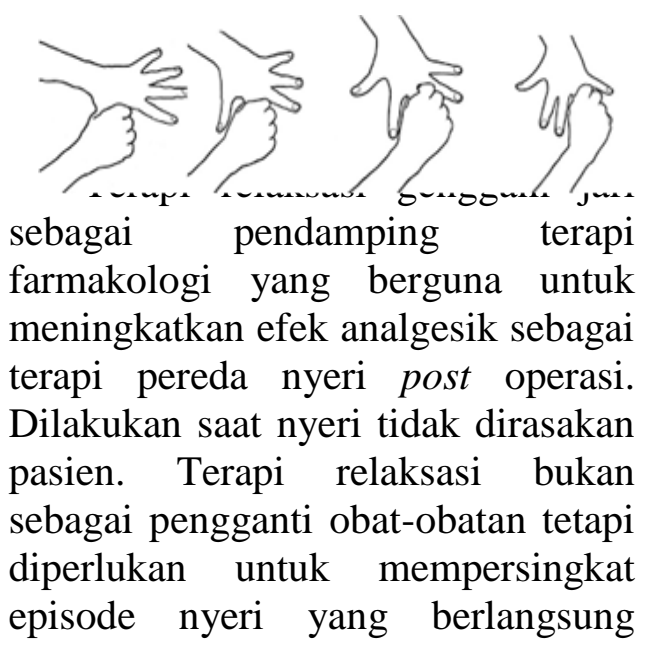


beberapa menit atau detik. Kombinasi teknik ini dengan obatobatan yang dilakukan secara simultan merupakan cara yang efektif untuk menghilangkan nyeri. Walaupun analgesik dapat menghilangkan nyeri dengan efektif, namun penggunaan analgesik akan berdampak ketagihan dan akan memberikan efek samping obat yang berbahaya bagi pasien (Rasyid et al., 2019).

Hasil penelitian jurnal kedua ini menunjukan responden sebanyak 10 orang. Karakteristik responden yang diambil yaitu pasien berusia antara 15 tahun sampai 50 tahun. Hasil sebelum dilakukan intervensi genggam jari yaitu nilai minimalmaksimal intensitas nyeri yang dirasakan pasien berskala 4-6 (nyeri sedang). Dan hasil setelah dilakukan intervensi relaksasi genggam jari yaitu nilai minimal-maksimal intensitas nyeri yang dirasakan pasien berskala 3-5 (nyeri ringan nyeri sedang). Sehingga pada jurnal ini teknik relaksasi genggam jari terbukti menurunkan tigkat nyeri pada pasien post apendiktomi.

Teknik relaksasi genggam jari yang dilakukan menunjukkan bahwa terapi relaksasi genggam jari memberikan respon positif sehingga jaringan otot lebih rileks, sirkulasi darah dan getah bening menjadi lancar, sehingga mampu menghilangkan asam laktat dalam serat otot yang mampu mengurangi kelelahan dan stress (F. Wati \& Ernawati, 2020).

Diketahui hasil dari kedua jurnal tersebut masing-masing memiliki keefektifan dalam menurunkan tingkat nyeri pada pasien post appendiktomi. Hal ini sejalan dengan penelitian (Rasyid et al., 2019) yang menyebutkan bahwa pada kelompok perlakuan diketahui sebelum dilakukan intervensi yang berada pada tingkat nyeri ringan yaitu 3 orang, dan paling banyak berada pada tingkat nyeri sedang 9 orang dan nyeri berat 9 orang. Dan saat setelah dilakukan intervensi, tingkat nyeri pasien mengalami penurunan yaitu 11 orang berada pada tingkat nyeri ringan dan 10 orang berada pada tingkat nyeri sedang.

Hal tersebut dikarenakan teknik relaksasi genggam jari ini merupakan teknik yang sangat sederhana dan mudah dilakukan oleh siapapun, yang berhubungan dengan jari tangan serta aliran energi di dalam tubuh kita. Menggenggam jari sambil menarik napas dalam (relaksasi) dapat mengurangi dan menyembuhkan ketegangan fisik dan emosi (Aswad, 2020).

\section{SIMPULAN}

Berdasarkan review jurnal diatas maka dapat disimpulkan bahwa adanya pengaruh dari teknik relaksasi genggam jarii terhadap penurunan tingkat nyeri pada pasien post operasi appendiktomi.

\section{SARAN}

A. Bagi Pasien Dan Masyarakat

Dapat memberikan informasi dan pengetahuan mengenai teknik relaksasi genggam jari sebagai pengobatan non farmakologis yang efektif dan mdah dilakukan.

B. Bagi Perkembangan Ilmu

Pengetahuan Dan Teknologi

Keperawatan

Sebagai bahan rujukan penelitian, meningkatkan 
sumber informasi dalam rangka peningkatan mutu dan pelayanan keperawatan secara mandiri yang optimal dengan cara menerapkan teknik relaksasi genggam jari sebagai tindakan non farmakologis pada pasien post apendiktomi.

C. Bagi Penulis

Dapat mengembangkan dan memperluas informasi mengenai pengaruh teknik relaksasi genggam jari terhadap penurunan skala nyeri pasien post appendiktomi.

\section{UCAPAN TERIMA KASIH}

Alhamdulillahirobbil'alamiin puji syukur atas kehadirat Alloh SWT yang telah memberikan limpahan Nikmat, Rohmat dan Karunia-Nya sehingga karya tulis ilmiah yang berjudul "Literature Review Pengaruh Teknik Relaksasi Genggam Jari Terhadap Penurunan Nyeri Pada Pasien Post Operasi Appendiktomi" dapat selesai tepat pada waktunya.

Penyusunan karya tulis ilmiah ini dijadikan sebagai salah satu syarat untuk menyelesaikan pendidikan gelar Ahli Madya Program Studi Diploma III Keperawatan Politeknik Yakpermas Banyumas. Dalam penyusunan karya tulis ilmiah ini penulis telah banyak mendapat banyak sekali bimbingan dan petunjuk dari berbagai pihak. Oleh karena itu, penulis mengucapkan terimakasih sebanyakbanyaknya kepada :

1. Rahaju Ningtyas, S.Kp., M.Kep. selaku Direktur Politeknik Yakpermas Banyumas.

2. Bapak Eko Julianto, A.Kep, S.Pd,M.Kep., selaku pembimbing I yang dengan penuh kesabaran memberikan bimbingan, pengarahan, kesempatan waktu serta saran dalam pembuatan karya tulis ilmiah ini mulai dari awal sampai akhir.

3. Bapak Ns. Sudiarto, M.Kep., selaku pembimbing II yang dengan kesabaran memberikan bimbingan, pengarahan, kesempatan waktu serta saran dalam pembuatan karya tulis ilmiah ini dari awal sampai akhir.

4. Seluruh dosen dan karyawan Politeknik Yakpermas Banyumas yang telah memberikan kenyamanan menuntut ilmu bagi penulis .

5. Kepada kedua orang tua yang tercinta, kakak dan adik saya yang senantiasa memberikan kasih sayang, dukungan semangat, motivasi dan do'a sehingga penulis dapat menyelesaikan karya tulis ilmiah ini dengan baik

6. Semua pihak yang penulis tidak mungkin sebutkan satu persatu yang telah membentu menyelesaikan penyusunan proposal karya tulis ilmiah ini

Semoga bantuan serta budi baik yang telah diberikan kepada penulis, mendapat balasan dari Allah SWT. Besar harapan penulis agar karya tulis ilmiah akhir ini dapat bermanfaat.

\section{DAFTAR PUSTAKA}

Astutik, P., \& Kurlinawati, E. (2017). Pengaruh Relaksasi Genggam Jari Terhadap Penurunan Nyeri Pada Pasien Post Operasi Sectio Caesarea Di Ruang Delima RSUD Kertosono. Strada Jurnal Ilmiah Kesehatan, 6(2), 30-37.

Aswad, A. (2020). Relaksasi Finger Hold Untuk Penurunan Nyeri 
Pasien Post Operasi Appendektomi. Jambura Health and Sport Journal, 2(1), 1-6. https://doi.org/10.37311/jhsj.v2i $\underline{1.4555}$

Bahri, F., \& Armiyati, Y. (2015). Penerapan Teknik Relaksasi Genggam Jari Untuk Menurunkan Nyeri Pada Pasien Post Operasi Apendictomy di Ruang Cendana Rumah Sakit Bhayangkara Semarang.

Bahrudin. (2017). Patofisiologi Nyeri (Pain). Fakultas Kedokteran Universitas Muhammadiyah Malang (E-Journal), 13(1), 713.

Bahrudin, M. (2018). Patofisiologi Nyeri (Pain). Saintika Medika, 13(1), 7. https://doi.org/10.22219/sm.v13 i1.5449

Brunner, \& Suddarth. (2015). Keperawatan Medikal-Bedah (12th ed.). EGC.

Cristina, A. (2012). Konsep Apendikitis Tanda Gejala Serta Konsep Nyeri. Экономика Региона, 10(9), 32.

Daulay, N. M., \& Simanira, F. A. (2019). Efektifitas mobilisasi dini terhadap penyembuhan luka paska operasi apendiktomi. 7(4), 245-248.

Hasaini, A. (2020). Efektifitas Relaksasi Genggam Jari Terhadap Penurunan Nyeri Pada Pasien Post Op Appendiktomi di Ruang Bedah (Al-Muizz) RSUD Ratu Zalecha Martapura Tahun 2019. Dinamika Kesehatan Jurnal Kebidanan Dan Keperawatan,
10(1), 76-90. https://doi.org/10.33859/dksm.v 10i1.394

Hayat, A., Ernawati, E., \& Ariyanti, M. (2020). Pengaruh Tehnik Relaksasi Genggam Jari Terhadap Penurunan Skala Nyeri Pada Pasien Post Appendictomydi Ruang Irna III RSUD P3 Gerung Lombok Barat. Malahayati Nursing Journal, 2(1), 188-200.

Komariah, A., \& Satori, D. (2011). Metode Penelitian Kualitatif. Alfabeta.

Kyle, \& Charman. (2015). Buku Praktek Keperawatan Pediatri. Jakarta : EGC.

Nurafif, kusuma dan. (2018). Tahnik Mekanisme koping dan Relaksasi nafas dalam Post Operasi Apendiktomi. Journal of Chemical Information and Modeling, 53(9), 1689-1699.

Oliver, J. (2013). Konsep Dasar Post Apendiktomi dengan Nyeri Akut. Journal of Chemical Information and Modeling, 53(9), 1689-1699.

Pann. (2019). Delmiter Teknologi Informasi.

Rahmatun, V., \& Heru, W. (2020). Penerapan Tehnik Distraksi Nafas Ritmik Untuk Menurunkan Nyeri Pada Pasien Post Apendiktomi. Jurnal Manajemen Asuhan Keperawatan, 4(1), 43-52. https://doi.org/10.33655/mak.v4 i1.81

Rasyid, R. A., Norma, \& Samaran, E. (2019). Article history: 
Keywords: 4(1), 1-21

Astutik, P., \& Kurlinawati, E. (2017). Pengaruh Relaksasi Genggam Jari Terhadap Penurunan Nyeri Pada Pasien Post Operasi Sectio Caesarea Di Ruang Delima RSUD Kertosono. Strada Jurnal Ilmiah Kesehatan, 6(2), 30-37.

Aswad, A. (2020). Relaksasi Finger Hold Untuk Penurunan Nyeri Pasien Post Operasi Appendektomi. Jambura Health and Sport Journal, 2(1), 1-6. https://doi.org/10.37311/jhsj.v2i 1.4555

Bahri, F., \& Armiyati, Y. (2015). Penerapan Teknik Relaksasi Genggam Jari Untuk Menurunkan Nyeri Pada Pasien Post Operasi Apendictomy di Ruang Cendana Rumah Sakit Bhayangkara Semarang.

Bahrudin. (2017). Patofisiologi Nyeri (Pain). Fakultas Kedokteran Universitas Muhammadiyah Malang (E-Journal), 13(1), 713.

Bahrudin, M. (2018). Patofisiologi Nyeri (Pain). Saintika Medika, 13(1), 7. https://doi.org/10.22219/sm.v13 i1.5449

Brunner, \& Suddarth. (2015). Keperawatan Medikal-Bedah (12th ed.). EGC.

Cristina, A. (2012). Konsep Apendikitis Tanda Gejala Serta Konsep Nyeri. Экономика Региона, 10(9), 32.

Daulay, N. M., \& Simanira, F. A. (2019). Efektifitas mobilisasi dini terhadap penyembuhan luka paska operasi apendiktomi. 7(4), 245-248.

Hasaini, A. (2020). Efektifitas Relaksasi Genggam Jari Terhadap Penurunan Nyeri Pada Pasien Post Op Appendiktomi di Ruang Bedah (Al-Muizz) RSUD Ratu Zalecha Martapura Tahun 2019. Dinamika Kesehatan Jurnal Kebidanan Dan Keperawatan, 10(1), 76-90. https://doi.org/10.33859/dksm.v $10 \mathrm{i} 1.394$

Hayat, A., Ernawati, E., \& Ariyanti, M. (2020). Pengaruh Tehnik Relaksasi Genggam Jari Terhadap Penurunan Skala Nyeri Pada Pasien Post Appendictomydi Ruang Irna III RSUD P3 Gerung Lombok Barat. Malahayati Nursing Journal, 2(1), 188-200.

Komariah, A., \& Satori, D. (2011). Metode Penelitian Kualitatif. Alfabeta.

Kyle, \& Charman. (2015). Buku Praktek Keperawatan Pediatri. Jakarta : EGC.

Nurafif, kusuma dan. (2018). Tahnik Mekanisme koping dan Relaksasi nafas dalam Post Operasi Apendiktomi. Journal of Chemical Information and Modeling, 53(9), 1689-1699.

Oliver, J. (2013). Konsep Dasar Post Apendiktomi dengan Nyeri Akut. Journal of Chemical Information and Modeling, 53(9), 1689-1699.

Pann. (2019). Delmiter Teknologi Informasi. 
Rahmatun, V., \& Heru, W. (2020). Penerapan Tehnik Distraksi Nafas Ritmik Untuk Menurunkan Nyeri Pada Pasien Post Apendiktomi. Jurnal Manajemen Asuhan Keperawatan, 4(1), 43-52. https://doi.org/10.33655/mak.v4 i1.81

Rasyid, R. A., Norma, \& Samaran, E. (2019). Article history: Keywords: 4(1), 1-21.

Rivalda, A. D., \& Fitriani, N. (2020). Dalam Pemenuhan Kebutuhan Aman Dan Nyaman.

Sasmito, A. B. (2018). Pengaruh Relaksasi Genggam Jari Terhadap Kecemasan Pasien Pre Operasi Benigna Prostat Hiperplasia (BPH). Journal of Chemical Information and Modeling, 53(9), 1689-1699.

Sugiyono. (2014). Metode Penelitian Pendidikan Pendekatan Kuantitatif, Kualitatif, dan $R \& D$. Alfabeta.

Sulung, N., \& Rani, S. D. (2017). Pengaruh teknik relaksasi genggam jari terhadap penurunan intensitas nyeri pada pasien post operasi laparatomi di Rumah Sakit Umum Daerah (RSUD) Deli Serdang Lubuk Pakam. Jurnal Endurance, 2(3), 397-405.

Sulung, Neila, Rani, Sarah, \& Dian. (2017).

Teknik

Relaksasigenggam Jari

Terhadap Intensitas Nyeri Pada Pasien Post Appendiktomi.

Tosepu, R. (2016). Epidimiologi Lingkungan Teori dan Aplikasi.
Bumi Medika.

Waisani, S., \& Khoiriyah, K. (2020). Penurunan Intensitas Skala Nyeri Pasien Appendiks Post Appendiktomi. https://doi.org/10.26714/nm.v1i 1.5488

Wati, F., \& Ernawati, E. (2020). Penurunan Skala Nyeri Pasien Post-Op Appendictomy Mengunakan Teknik Relaksasi Genggam Jari. Ners Muda, 1(3), 200. https://doi.org/10.26714/nm.v1i 3.6232

Wati, R. A., Widyastuti, Y., \& Istiqomah, N. (2020). Comparison Of Classical Music Therapy And Finger Clothing On The Decrease Of Appendictomy Pain. 2(2) 